\title{
Recruitment infrastructure within the agricultural and agrifood sector: Post-Soviet and neocolonial entanglements between "Eastern" and "Western" Europe
}

\author{
Dina Bolokan ${ }^{1}$ *
}

${ }^{1}$ University of Basel, Department of Social Sciences, Rheinsprung 21, 4051 Basel, Switzerland.

KEYWORDS

Agriculture

Recruitment

Neocolonial labor

regimes

Circular migration

Post-Soviet citizenship
A BSTRACT

The COVID-19 pandemic brought into focus how nationstates manage to shut down borders while maintaining flexible labor recruitment. This challenging situation provoked more public discussion around inequalities within the agricultural and agrifood sector. However, reflections around labor conditions have remained limited. I argue that instead of merely pointing to certain aspects of the current labor conditions and demanding more regulations, a different point of departure is urgently needed. Through a genealogical approach to recruitment and rotation, this article aims to further politicize the discussion around the current recruitment infrastructure in the agricultural and agrifood sectors in Europe. I do this with my research on labor migration from Moldova to the European Union and Switzerland, where I consider the hypermobile life trajectories of workers within the agricultural sector. I am interested in the structures, goals and biopolitical implications as well as the involved ideologies that accompany the laws and regulations of the legal framework of such hypermobility between "Eastern" and "Western" Europe. I show how the involved citizenship laws and circular migration policies reveal entanglements through time and space that lead to neocolonial and post-Soviet regimes of labor control within Europe.

\footnotetext{
* Contact address: bolokan@protonmail.com (D. Bolokan)
} 
D. Bolokan - Recruitment infrastructure within the agricultural and agrifood sector ...

Oleg: See, our country oppresses us, pinches us, kicks us out. Go somewhere to work in another country. This has to do with rising prices on oil, housing, utilities and food. I don't know how many times the prices have gone up lately. That's why they kick us out. (...) There are people who have millions. They take care of themselves, of nothing else. But if you are Petya, Wasja or anyone else, then, well. Everything is ok with me, so what the heck. I think they think we are assholes.

Me: You mean those who have money?

Oleg: What do you think they think we are human? They think we're some kind of rascals. (...) It shakes you all the time because you don't know what tomorrow is. Tomorrow we will sell you as slaves to Africa or America. Package wise. That's our life.

(Talk with Oleg from Ukraine, working on a Swiss farm, 2013)

\section{Introduction}

An immense number of workers, mostly with subsistence farming backgrounds, travel annually for short-term work abroad in agriculture and the agrifood sector. Germany recruits annually around 300,000 workers, Switzerland around 35,000 and Italy around 370,000 (FAO 2020). Most of the workers in these and other wealthy regions in Europe arrive from low income "Central" and "Eastern" European countries - mainly Poland or Romania, but also from "North" African countries such as Tunisia and Morocco. At the beginning of the COVID-19 pandemic in spring 2020, when borders were shut down even between European member states, many agricultural workers faced the problem of not being able to leave for work abroad. At the same time, the Food and Agriculture Organization suspected a shortage of about one million seasonal agricultural workers across Europe (ibid.). In the following weeks and months, the European Commission developed guidelines to extend flexibility to seasonal agricultural worker recruitment (EC 2020). Different strategies allowed for the maintenance of agricultural production: In France, local governments reached out to accommodation centers to recruit recognized refugees as agricultural workers. The German 
government tried to recruit asylum seekers to fill labor gaps and lifted the ban on seasonal agricultural workers, allowing the sector to recruit 80,000 people in April and May. The Netherlands, UK, Italy, Belgium, Austria and Ireland, among others, chartered flights to bring in tens of thousands of seasonal agricultural workers from Romania and other "Eastern" European countries.

All of these developments came in parallel with high numbers of infections among employees in meat processing factories across Europe and stirred public debate about what workers have been protesting against for many years: the highly disastrous working and living conditions of people that labor in slaughterhouses all over Europe, including Belgium, France, Ireland, Spain and Portugal. The meatpacking industry in Germany is especially large, and the situation for workers is especially bad. Southern Spain and Southern Italy supply European supermarkets with fresh fruit and vegetables all year long, but it is the large-scale slaughterhouses in Germany that supply large parts of the EU with meat and even export to China. Workers who fall ill risk being fired and therefore work as long as their legs are still able to carry them. Additionally, people often live in moldy apartments with several people in a room. These labors and living conditions lead to consequences for workers' health and make them especially vulnerable to COVID-19. While these conditions of food production rightly generated public interest, criticism remained limited. Topics included: low prices for meat, deductions on workers' salaries for accommodation and transport and insufficient air filtration systems to prevent virus spread. Trade Unions also criticized the system of sub-subcontractors stemming from Werkverträgen, that is, the labor contract system, that bypasses minimum wages and outsource responsibility for the given working conditions. Others pointed to the overall rise of the profit margin for supermarkets and involved companies and criticized the market and concentration of power in the food industry.

The COVID-19 pandemic once again clearly demonstrated (1) how governments manage to both shutdown borders and maintain flexible labor recruitment - something that has been practiced for many decades. (2) The 
radical limitation of formulated critique in public discussions and academia that views increasing regulations as the only solution. As such, this article aims to broaden both public and scientific discussions by analyzing the involved policies that accompany such precarious labor relations beyond the COVID-19 pandemic. These labor structures are characterized by hypermobility, a mobility regime where workers from abroad are recruited for a certain amount of time and then made to leave again. I argue that what is missing in the current discussion is an overall understanding of the structures, goals, biopolitical implications and involved ideologies that accompany today's labor mobility within the European Union. I further argue that tracing back the genealogies of these structures is necessary to understand current regimes of labor control as well as of recruitment and rotation within the international division of labor, which manifests itself in the agricultural and agrifood sector. Following Kien Nghi Ha, it is clear that labor migration policies in Germany reveal colonial patterns that remain present (Ha 2003).

This article mainly focuses on the recruitment infrastructure between Switzerland and Moldova. It analyzes how these two countries are connected with European policies and the overall hypermobilization of workers and the institutionalization of mobility control. Neither Moldova nor Switzerland is part of the European Union but both countries are nonetheless affected by its politics. While Switzerland lies in the center of Western Europe, Moldova is at its borders. And, while Switzerland is one of the richest countries in the world, Moldova is one of the poorest. Such contrasts make power relations most visible: while Switzerland does not want to be a member of the European Union, Moldova is not allowed to. Hence, this text discusses how labor mobility in the agricultural sector and beyond - mobility of those who move from the post-Soviet global peripheries to wealthier European countries - is currently being channeled, mediated and thereby controlled while at the same time people are ethnicized/racialized.

This research is based on a long-term study between 2011 and 2019. I am interested in which policies and stakeholders are involved in the process of expanding and implementing the recruitment infrastructure of agricultural 
workers between Switzerland/ the EU and Moldova - policies that push forward what I refer to as hypermobility (Bolokan 2021). In this article I first elaborate on the history of labor recruitment in the agricultural sector in Europe; then, I discuss the labor relations between Germany and "Eastern" European regions in order to trace back the conditions of the underlying regimes of labor control by looking into genealogies of rotation. I then map the recruitment infrastructure between Moldova and Switzerland and the EU by looking into current mobility agreements, post-Soviet citizenship practices and development strategies that facilitate hypermobility and just-in-time recruitment. In the end, I reflect on the structures, goals, biopolitical implications and involved ideologies of today's labor mediation in agriculture and the agrifood sector. Doing so, I propose to change the starting point for reflection, moving towards an inclusive reflection about social justice in regard to food production.

\section{Migration and labor recruitment in the agricultural sector in Europe}

Scholars on migration infrastructure have observed an increase in international so-called "low-skilled" labor migration since the late 1990s (Xiang and Lindquist 2014, 122). The same has been said for the agricultural sector and meat processing industry that are often at the forefront of labor recruitment (Martin 2017, 3). While focusing on Asia and the Middle East, Xiang and Lindquist state that the "increasing level of mobility due to the extension of market forces and the enhancement of state regulatory capacity" is a "dual development in the broader political economy" that goes hand in hand with the "intensification of mediation and infrastructural involution", meaning that labor migration has become more accessible and more restrictive at the same time (Xiang and Lindquist 2014, 125). Whether, and to what extent, this also applies to the agricultural sector in Europe is not clear, especially in the wealthier "Northern" European countries where little research on current agricultural labor migration exists. 
The United Kingdom, France, Switzerland and Belgium pioneered labor recruitment in the 1940s. Germany, the Netherlands and Austria followed later, and in the end, practically all industrializing European countries developed some sort of systematic temporary recruitment program for workers from abroad (Castles 2006, 742). In Switzerland, a Saisonnierstatut (statute for seasonal workers) was introduced in 1931 to regulate short-term residence permits for workers from abroad until 2002. In the beginning, it allowed workers to be employed in Switzerland for a few months, a "season", and to return for the following season. Hence Switzerland pioneered the introduction of a rotation principle within a transnational organized labor market. The goal was to recruit workers for the growth of the national economy without settling them in Switzerland in the long term. But many workers still found a way to settle down and bring their children that were then illegalized (Frigerio 2014) as permanent settlement was not intended by the government and reunification of families was forbidden. Authorities allocated work permits on an annual basis according to the needs of the different sectors. The so-called Saisonniers (seasonal workers) were not allowed to change jobs or move their residence to another canton during their stay. Some provisions were later relaxed. The so-called unskilled labor force, with low wages in sectors such as the domestic economy, agriculture, textile, metal and machine industries, could be sent back quickly when not needed anymore.

Germany signed its first bilateral agreements with Italy in 1937 during Nazi Germany. It was intended to fill a need for laborers in the arms industry and agricultural sector. This Anwerbeabkommen for so-called guestworkers was then expanded in 1955-68 by implementing a labor regime that was based on strong state regulations. This system recruited workers for a limited period while restricting their rights and possibilities of family reunion (Castles 2006, 742). Other countries introduced recruitment programs for the agricultural sector mainly after the Second World War. The Seasonal Agricultural Workers Scheme in the UK was implemented in 1945 (Consterdine and Samuk 2015, 4). Aiming to bring in young people during the labor-intensive months, this 
program was designed to be a cultural exchange arrangement for agricultural students from across Europe and later emerged as a way of recruiting workers to fill labor market demands (Consterdine and Samuk 2015, 4). Though there are persistent recruitment strategies such as in France (see "the IMOs", Morice and Michalon 2008), many European countries restricted labor migration in the 1970s and reintroduced recruitment programs at the beginning of the 2000s (Castles 2006).

The return to temporary labor migration policies has been addressed as a partial resurrection of guestworker programs (Castles 2006; Nita 2016). In the case of the UK, most workers were recruited from Poland, Ukraine, and the Baltic States, all countries that, with the exception of Ukraine, joined the EU in 2004 (Castles 2006, 752). Further recruitment programs have been developed in Germany, the Netherlands, Norway, Ireland, Belgium, Sweden, Greece, Italy, and Spain (Castles 2006, 751). An overall mapping of the agricultural recruitment infrastructure in Europe is not within the scope of this article, but it is central to keep in mind that the agricultural workers in all of these countries were mainly recruited from "Eastern" and "Central" Europe such as Poland, Romania, Bulgaria, the Slovak Republic, Croatia, Hungary, Ukraine, Moldova, Russia and Belarus (Castles 2006; Consterdine and Samuk 2015, 5). At the same time, many Eastern European countries upheld relatively liberal migration regimes (that is, no visa requirements) with their neighboring countries before becoming EU candidates. The forced adaptation of restrictive migration policies arrived at the same time as the closing of borders towards the "East". The implementation of new national laws to maintain liberal labor migration was needed (Szulecka 2016, 52), and this impacted the mobility regime along the new borders.

So, the temporary recruitment programs that exist in the European agricultural sector today represent an infrastructure that stems back to the Second World War. Current labor relations in the European agricultural sector are further based on informal recruitment such as the caporale system in Southern Italy that has also existed for decades (Perrotta and Sacchetto 2014; Perrotta 2015). Most of the workers in these regions in the last years 
come from "'West and East Africa' (mainly Burkina Faso, Ghana, Mali, Senegal and Ivory Coast) and from 'Central and Eastern Europe' (mainly from Romania and Bulgaria)" (Perrotta 2015, 199). Provoked by uprisings of badly exploited and often illegalized (Bauder 2014) agricultural workers, recent research has explored the transformation of Mediterranean agriculture (Gertel and Sippel 2014; Corrado et al., 2017) and pointed to the intersection of agriculture and migration with experiences of racialization/ethnicization (Azzeruoli 2017; Chantal 2017) along with gendered exploitation (Hellio 2008; Peano 2017).

The formalized recruitment programs and informal brokerage systems in the agricultural sector build an infrastructure that differs regionally but shares a key systematic goal. As present-day workers have to be flexible and mobile (Boeckler and Berndt 2014; Molinero-Gerbeau and Avallone 2016, 137ff), this neoliberal migration and mobility regime serves the top-down regulation of workers' rotation according to the specific temporal and geographical needs of the capitalist agricultural labor markets. Rotation in this context is not just used as a descriptive term to grasp how labor and labor division is organized. Rotation in this analysis is understood as embedded and linked to highly controlled regimes of labor control. Regimes of rotation are not to be understood only in terms of recurrence, repetition and return. Instead, they need to be situated within historical structural power relations to deconstruct any underlying understanding of natural given labor conditions.

The rotation regime can be more regional, such as for the "particularly undocumented immigrants and asylum seekers who have crossed the Sahara, Libya, and Mediterranean to reach Italy- follow the harvest cycle in the regions across southern Italy. In winter they pick citrus fruit in Calabria, in the spring they pick strawberries in Campania, and in the summer, they pick tomatoes in Puglia and Basilicata regions." (Perotta 2015, 198). In other cases, the rotation regime is transnational, such as in the case of agricultural workers from Moldova: Since people from Moldova are increasingly able to cross borders legally and officially gain access to the European labor market, the 
first years of labor migration are often characterized by extremely mobile back and forth movements, following short term labor relations in different countries, leading to transnational hypermobility that by "no means just follows the 'natural' seasonality of agriculture" (Bolokan 2021).

The introduction of so-called circular migration has been described as resembling the guestworker schemes as "receiving countries can match their labor market needs without offering possibilities for permanent settlement" (Nita, 2016). It allows for temporary labor recruitment via bilateral agreements to circumvent European two circle migration policies. Research expounding on the problems of the implementation of circular migration policies between Moldova and the European Union (Nita 2016) lack a broader understanding of the political economy of what could be referred to as modernized guestworker policies. They also do not make transparent the framework that is driving their studies and these policies. They describe circular migration processes as the "back-and-forth movement of people" that is a "part of the changing nature of migration" (Solé et al. 2016). This leads them, for example, to propose extending bilateral agreements to multilateral ones so that the "European Commission could play an increased coordinating role in this regional endeavour which would make the EU-Moldova Mobility Partnership really deserve its name" (Nita 2016, 42).

\section{Theoretical background: Genealogies of flexibilization and rotation in labor migration policies}

Kien Nghi Ha asserts that perception of the guestworker policy is often understood from the political "hour-zero-myth", thereby placing migration policies in a contemporary historical vacuum (Ha 2008, 16). According to Ha's derivation, the emergence of these labor migration policies in Germany is closely interwoven with colonial history, exhibiting colonial patterns up until today; this de-historicization is accompanied by a de-thematization and deproblematization. He argues that this de-historicization is tantamount, on an epistemic level, to a "secondary colonialization", since it bleaches out 
knowledge and the possibilities of reparative remembering processes (Ha $2008,17)$. In order to situate the current recruitment infrastructure between Switzerland/ the EU and Moldova, a genealogical understanding of these regimes of labor control is required, which I derive from Ha's analysis of labor migration policies within Europe, especially Germany.

According to $\mathrm{Ha}$, a colonial practice can be seen as a racially connoted appropriation and devaluation of the so-called "other", which encompasses spatial, cultural and socio-economical domains. He argues that it is precisely through migration and biopolitical processes that these spheres can be appropriated; this process works such that the organization and control of human resources are the fundamental elements of colonization. While external colonization was initially based on different exploitation systems of forced labor (such as slavery, indentured servants, redemption systems, and contract work), colonial labor relations were later increasingly internalized and modernized. Initially, labor migration took place from the European colonizing countries to the new colonies. This changed in the course of European industrialization when the recruitment of workers from dependent areas became a racist economic instrument intended to strengthen national competitiveness. The "imperialist worldview" underlying this is a statepromoted ideology that tries with all available means to enforce its own national power position among colonial powers competing for global resources. Ha argues that through the shift of direction of colonial labor migration, an expansion of the discriminatory practices of appropriation then took place inside the colonizing regions in Europe (Ha 2008, 18ff), leading to internal colonization (innere Kolonialisierung) (ibid. 21).

It was not an accident that the emergence of a nation-state migration policy in Germany coincided with the implementation of a nation-state colonial policy. Since, according to Ha, the elites of the Wilhelminian colonial society shared nationalist, anti-Semitic, racist, social Darwinist, imperialist and militaristic ideologies, it would require explanation if these ideologies would not also have impacted labor and migration policies. The connection between external and internal colonization hence developed simultaneously 
in Imperial Germany. While the colonial nations were establishing their rule in the colonies, Prussia started to employ workers from "Eastern Europe" under conditions that - following contemporary agricultural historians and recent historical work - amounts to the "existence of lawless wage slaves" (Herbert 2003, 37 in: Ha 2016, 176). Historians also show how workers at that time were discriminated against as "low ranking Slavs" and racially labeled as "born earth workers" (geborene Erdarbeiter) or "Wulacker" (from the German word wühlen, to grub) (Bade 1992, 322 in Ha 2016, 176). Later, the National Socialists took over the political discourse of the Wilhelmine colonial society and declared "Slavic sub-humans" to be the "working people" of the Aryan "master race" and started striving for a racial-political systematic reorganization of Europe, including an ethnic division of labor (Ha 2016, 175).

Imperial Germany already introduced the so-called "waiting period regulation" (Karenzzeit-Regelung) in 1907 (Bade 1992, 314 in Pagenstecher 1994), a principle of rotation that formed the basis of later guestworker policies (Ha 2003, 70ff). This complex system of bureaucratic rules was developed to closely control labor migration and recruitment. Central to this was the "compulsion to legitimize" (Legitimationszwang) and the "compulsion to return” (Rückkehrzwang) (Bade 1979, 446ff). “Compulsion to legitimize" meant above all that immigration was strictly regulated: families were not allowed to enter together and children were generally forbidden to enter. If workers became pregnant during their stay in Germany, they were expulsed. The residence permit was only valid for one year and was tied to a specific employer. Anyone who did not agree with the working conditions or who received a better offer could not change employers. The "obligation to return" associated with these regulations meant that the workers had to leave Germany at the end of the season in order to spend the "waiting period" in winter outside the country (Bade 1979, 447). According to Ha, this rotation system, materialized through the legitimation card (Legitimationskarte), contains "elements of temporary serfdom", since neither freedom of contract nor freedom of movement existed and thus fundamental workers' rights were denied. This card of legitimization survived four different systems of society 
from 1912 onward. Together with the racist compulsion to return, which provided for the annual deportation of the so-called "foreigner Poles", this coercive relationship was not only an instrument of labor law but also of the police. Labor law was thus subject to strict bureaucratic surveillance and control by authorities, building the basis for a forced flexibilization and rotation of employment relations. These regulations built the basis to ban workers from leaving the country or to deport them whenever necessary. Nazis later made intensive use of such policies (Ha 2003, 75ff).

By expanding the increasingly administrative and centrally organized system of temporary worker recruitment, the German Reich became the second-largest labor importing country in the world, just after the US, until the First World War. In 1910, 1.26 million workers from abroad were employed in the German Reich. Two-thirds of the employees came from Polish regions of Austria-Hungary and Russia (Ha 2008, 26). Historians have shown that despite criticism from local authorities, the semi-peripheral regions of Eastern Europe were considered to be the "recruitment areas" and "free hunting grounds" (freie Jagdgebiete) of Prussia (Bade 1984, 444ff; Bade 2000, 224ff in Ha 2003, 78). These "hunting grounds" changed as a result of the self-ignited world wars. Germany had to give up both its non-European colonies and the Nazi occupations, and had hence to give up its traditional labor recruitment areas in Eastern Europe during the Cold War; it turned to the so-called "guestworkers" from the countries bordering the Mediterranean (Ha 2008, 25).

According to $\mathrm{Ha}$, the conception of state policies of labor migration can thus be roughly divided into two phases: in the 19th century until the First World War, it was primarily the inner-European semi-periphery that served as what historians refer to as the "human resource warehouse" (Rohstofflager); in the second phase after the Second World War, the recruitment area was increasingly extended to the postcolonial world in order to satisfy the growing demand for "cheap" labor. This tendency encompasses all colonizing European countries, with of course very different specificities: since the 1950s, workers from England's so-called "Irish backyard" have been 
supplemented by workers from the Caribbean and South Asia, and have even been replaced in the most marginalized labor areas. France, which traditionally recruited workers from the peripheral areas of Spain and Italy, also started to recruit workers from the formerly colonized francophone societies in Africa (Ha 2008, 25).

Since its beginnings, state policies of labor migration have been regarded as a means of skimming off "human capital" from the peripheries (Ha 2008, 23). This connection is particularly evident in the national economic cost-benefit calculation. So-called "rearing costs" in the Imperial era that could be saved by such practices were recorded as saved socialization and training costs in the national budget during the guestworker era. It was calculated that the guestworkers made at least 20,000 Deutsche Mark in profit per year after deduction of all expenses. In addition, there were billions of Deutsche Mark in surpluses for the German social security system, since the guestworkers did not receive equivalent benefits (Ha 2008, 28). While Germany argued that guestworker schemes were development aid for the countries of origin and promoted their recruitment programs as their contribution to European integration (Herbert and Hunn 2007, 704ff), a political-economic analysis reveals that the opposite took place (Ha 2003, 69). In this calculation, the recruiting national economies "win" twice: they gain external resources and save costs while the countries of origin have to bear losses and costs. According to Ha, discriminatory labor migration policies can therefore be seen as a reversal of colonial forms of expansion, which allow for the appropriation of the productive power of "the others". It follows a logic where migrating workers are defined and threaded as "freely displaceable objects of consumption" (Ha 2008, 28). So, while the recruitment initiatives also emanated from the sending states (Jamin 1998, 69) and the German side saw their role as a kind of development aid (Herbert and Hunn 2007, 704ff), the narrative of aiming to help has to be put into the right genealogy. According to Madina Tlostanova, the "rhetoric of salvation [is] hiding the colonial logic of control, domination and suppression" throughout history up until today (Tlostanova 2012, 132). 
D. Bolokan - Recruitment infrastructure within the agricultural and agrifood sector ...

The consequence of the guestworker regime was an ethnicized division of labor accompanied by the marginalization of workers from abroad and the introduction of a new lower class in society (Unterschichtung). The implementation of an "underclass" (Unterklasse) was inscribed in labor and migration laws with terms such as Inländerprimat (domestic primacy). This primacy provides for a general preference for Germans and EU citizens and is hence accompanied by a hierarchical ethnic division of labor (Ha 2008, 28). At the same time, the existence of an ethclass (Ha 2003, 74) enabled many German citizens at the lowest rung of the social ladder to rise professionally and socially. This sub-proletarianization created an ethnically stratified underprivileged class (Ha 2003, 74). Asymmetrical social relations along ethnically defined borders are a characteristic feature of colonial and apartheid states. Thus, the degree of impermeability of these borders provides information about the effectiveness of structural racism which, according to Ha, must be problematized as the "effects of social imperialism" (Ha 2008, 31).

Warning against a universalizing and ahistorical view, Ha stresses the fact that colonial discourses are conceived and implemented differently in today's labor migration according to temporality and local context. He advocates for an understanding of the transformations and fragments of colonial structures through their dynamic developments and fragility. Ha further argues that labor migration patterns to this day remain subordinate to a nationalist imperative that seeks to defend its own position of power in the increasingly fierce competition between Western economies. Ha also points out that although there are important differences between Wanderarbeiter (Weimarer Republic), Fremdarbeiter (Nazi Germany), and Gastarbeiter (postwar-Germany) (itinerant/migrant worker/ forced laborer, "foreign worker" and guestworker) - they should by no means be equated - they can only be grasped in historical context. Given the fact that the main elements of guestworker schemes stem from the labor migration legislation of Colonial Germany, and their traces can still be seen today, the continuities remain analytically important (Ha 2003, 61ff). 


\section{Methods: Genealogies, entangled policies and transnational perspectives on recruitment infrastructure}

This article aims to situate labor regimes in the agricultural and agrifood sector between "Eastern" and "Western" European countries, by looking into the recruitment infrastructure. This analysis is based on my transnational research on labor migration mainly focusing relations between Moldova to the European Union and Switzerland. Between 2011 and 2019 I conducted biographical interviews with 34 agricultural workers at various moments throughout their different living and working conditions. They mainly worked in agriculture and the agrifood sector and were mostly from Moldova but also from Ukraine, Romania and Poland. Based on these interviews and on ethnographic research, I observed the hypermobile life trajectories of workers that regularly commuted between their own farm - as most of them are subsistence farmers - and the place where they perform wage labor for years. I follow up on these observations and on the phenomena that I refer to as hypermobility (Bolokan 2021) and look into the legal conditions of the underlying recruitment infrastructure. I focus on those recruiters/mediators, agencies and institutions that have been directly or indirectly involved in organizing the transnational labor relations of those workers I talked to in order to map this infrastructure.

Xiang and Lindquist define migration infrastructure as "the systematically interlinked technologies, institutions, and actors that facilitate and condition mobility" $(2014,124)$. Based on - and in further development of - this analytical framework, I understand recruitment infrastructure as systematically interlinked formal and informal networks, institutions and regulations that facilitate, condition and control the recruitment of workers. There is a risk of reproducing a methodological nationalism, thereby making invisible how labor migration, mobility and recruitment is impacted by transnational developments and tied to entangled histories (Conrad and Randeria 2002; Randeria 2012). Furthermore, I develop a genealogical approach where I derive the contours of my understanding of genealogy from 
Foucault $(1977,139 \mathrm{ff})$. This approach traces not "origins" (Ursprung) but it looks into "descent" (Herkunft), as "it finds not the purity and promise of a beginning but a series of instaurations of power" (Shiner on Foucault, 1982, 387). As a methodological framework, I am therefore guided by a transnational and genealogical point of departure, taking the transnational entanglements through time and space into consideration when looking into the hypermobility of workers and the recruitment infrastructure involved. I define three dimensions of analyzing such infrastructures: (1) entangled policies (related regulations and their historical configurations), (2) transnational connections (related actors and institutions in different places) and (3) the logics, goals, biopolitical implications, power relations and ideologies involved.

My mapping of the recruitment infrastructure focuses on observations, government reports, institutional papers and interviews with 16 people from brokerage agencies, the International Organization for Migration and nongovernmental organizations operating in Switzerland and Moldova. While some mediators that I interviewed work for independent recruitment agencies, others are organized within development programs operating in Moldova and are financed by the Swiss Agency for Development and Cooperation. Two interviewees were staff members of the Federal Department of Foreign Affairs (FDA) in Switzerland and six interviewees were staff members working for the Swiss Farmers' Union (SFU) and Agrimpuls (a branch of the SFU). In Moldova, I talked to the staff of the International Organization of Migration and to an FDA funded NGO (NEXUS) that implements circular migration policies. Further interviews were conducted with individuals who collaborate with Agrimpuls in Switzerland. Additionally, interviews in Moldova were conducted with agencies that broker workers to all European countries, especially to food processing factories in Germany, Poland and Denmark. The length of the interviews ranged from 60-120 minutes. 


\section{Agricultural recruitment infrastructure between Moldova and Switzerland/ the EU}

After the collapse of the Soviet Union, labor recruitment into the EU took place informally and illegalized people due to the absence of a legal framework for officially granting work permits. Since then, migration has become increasingly regulated and has allowed for labor relations even though Moldova is not part of the European Union. Considering the recruitment infrastructure between Moldova and Switzerland/ the EU allows us to understand modernized regimes of labor control at the nexus of postSoviet and postcolonial power relations that are widely under-researched.

The most frequent recruitment pattern for those who work in the agricultural and agrifood sector is personal connections: people follow friends or relatives who have already been working abroad. Nevertheless, some people in Moldova rely on agencies for finding work abroad and recruitment via digital platforms is on the rise. From the Swiss side, farms either rely on already established labor relations and networks in the countries of origin or they contact a branch of the Swiss Farmers' Union (SFU) in the corresponding cantons. A rare recruitment practice is the consultation of regional employment centers in Switzerland (RAV), digital online platforms or further associations. Most employment relations take place on legal grounds, but several thousand illegalized agricultural working relations exist in Switzerland. When they come to work, people are mainly employed on one farm, but in some rare cases, multiple farms take turns with one worker.

In the following section, I focus on the most relevant agreements represented in the recruitment infrastructure that allow legal mediation for laborers between Moldova and Switzerland and the European Union. This includes identifying policies, institutions and stakeholders-the overall structures that are involved in organizing peoples' movements - and pointing to the central rules, regulations and guiding principles. Whenever possible, I briefly refer to other regions in my analysis in order to draw attention to the extent of transnational interdependence. 
Agricultural traineeship regulations

According to the Stagiaires Agreements, workers from abroad can undertake wage labor in agriculture in Switzerland. The first agreements were created in the 1950s and have since been signed with 13 countries (SEM 2019). These agreements build the basis for recruiting workers from Ukraine and Russia. Recruitment from Moldova, however, is regulated via agricultural traineeships within the framework of Swiss aid and development projects (via art. 37 VZAE) (see SEM 2020, 4.7.6.). Agroimpuls (today Agrimpuls), a branch of the Swiss Farmers' Union since 1991, organizes most of the traineeship recruitment. They are financed by the Swiss Federal Department of Foreign Affairs and therefore supported by development policies and funding and hence understood as aid for so-called underdeveloped countries. Agrimpuls works together with private agencies or with Catholic relief and development organizations such as Caritas in Romania. As in Moldova, Ukrainian and Polish universities are also partnering and becoming a growing part of the recruitment infrastructure: students are offered language courses to prepare for work in the agricultural sector in wealthier European countries. Although these traineeships are being implemented as a kind of exchange program, the "trainees" work just as regular workers on the farms. Hence, their work is devalued and deskilled: in the Swiss case, these students, many with rural farming backgrounds, are allowed to enter the labor market on trainee salaries. According to farmworkers who come via these regulations, the socalled trainees are not sent to the farms where they would learn skills to eventually benefit their farms at home; instead, they are sent to locations according to Swiss farmers' needs and gender preferences. This "exchange" is only possible once in a lifetime and is limited to workers under the age of 30 , which guarantees not only educated and experienced workers, but also a young labor force recruitment. Universities, especially in Ukraine, offer language courses from the first semester to prepare students for work abroad. As students study agronomics, tourism or engineering, they also choose whether they want to learn English, German or French. Private recruitment agencies organize events at universities to hire these young people directly. 
They even help with formalities such as registering at a university, "proving your rural background" and other administrative barriers.

The permits based on agricultural traineeship via art. 37 and the Stagiaires Agreements are subject to annually fixed separate quotas as is the case for further work permits for non-EU/EFTA citizens (art. 20 Federal Act on Foreign Nationals and Integration). Although the workers entering under these agreements represent a minority on Swiss farms, these permits can be expanded according to the needs of the agricultural labor market. The traineeship regulations that especially broker young people from outside the European Union were especially important as a recruitment channel before the eastern enlargement of the EU. After that, they declined slightly (from 2127 in 2002 to 1682 in 2005) and the annual report of the Swiss Farmers' Union declared: "finally, workers from the East" (Swiss Farmers' Union 2005). Today, these traineeships often serve as the first step into the Swiss and the European labor market for young workers that do not yet have European citizenship.

\section{Post-Soviet citizenship practices}

The current territory of the Republic of Moldova was a part of Greater Romania from 1918 until the Second World War when it became part of the Soviet Union. After the collapse of the Soviet Union in 1991, Moldova became a nation-state bordering Romania to the West and Ukraine to the East. Moldovans can apply for Romanian citizenship by claiming co-ethnicity and proving that their ancestors had previously lived in the territory of former Great Romania. This Romanian citizenship, alongside jus sanguinis, allows access to the European labor market for people from Moldova, although Moldova is not part of the European dual migration system: citizens from non-EU countries only have the right to work in Switzerland and in EU countries in exceptional cases (this includes mainly so-called highly qualified workers). 
Before 2009 only a few thousand people applied for a Romanian citizenship per year (Knott 2019, 999). This number rapidly accelerated since then: Today about 700.000 Moldovan citizens also hold a Romanian citizenship. According to an official request of information at the Romanian National Authority for Citizenship (Autoritatea Națională pentru Cetățenie) about 100.000 citizenship requests are pending (see Necșuțu 2020). Additionally, Moldovan citizens can also receive a Bulgarian citizenship by claiming co-ethnicity. These practices hence build the central legislation of the labor recruitment infrastructure. Similar post-Soviet citizenship practices based on co-ethnicity that enable non-European citizens to access the European labor market also exist between further countries (Dumbrava 2019). Hungary, for example, has had a citizenship law for co-ethnics from Serbia and Ukraine since 2011. All of these citizens, as those from Moldova, do not appear in official statistics on labor migration or in the public reception as workers from outside the European Union; instead, they are counted under their European maintained citizenship.

As workers coming via Romanian citizenship are regarded and registered as Romanian citizens, they most often receive a short stay permit (L-residence permit) in Switzerland, which is issued for between three months up to a year. Working contracts in agriculture are mostly issued for several months, and so is this permit, although workers could theoretically prolong their permits to search for a job if local authorities agree. Changing place of employment in this case is theoretically legal, but only when it is considered to be for a "good cause" (art. 32 Federal Act on Foreign Nationals and Integration: para. 3). Workers therefore mostly try to endure the conditions where they work. While holding a short stay permit, workers are directly and indirectly excluded from rights that local workers have and face more control. For example, they have to pay into the unemployment insurance scheme, but they usually cannot receive unemployment benefits, as the required minimum contribution period contradicts with the temporality of the agricultural labor relations. Their status is fragile because it is tied to the working contract and they must leave Switzerland several months after the 
job ends. Family reunification is allowed on paper, but practically impossible due to obligations that again contradict the social status of the workers (e.g. accommodation requirements). Switzerland has developed a finely tuned system where workers have some rights on paper, but where in reality access is difficult given their agricultural living and working conditions. As a result, most workers leave the country as soon as their agricultural employment ends. These citizenship practices build the legal framework for people from Moldova to be recruited to Switzerland. However, the specific conditions in the agricultural labor market and the overall power relations make it practically impossible for workers to settle down in Switzerland, where they perform wage labor.

A further central logic of the infrastructure is how practices and discourses around co-ethnic citizenship policies entangle and coincide with ethnicized/racialized inclusion and exclusion. After the collapse of the Soviet bloc, Romania as well as other Central and Eastern European countries implemented national reproduction regimes that included co-ethnics via citizenship and excluded ethnic minorities through "various interventions at the physical, legal, and symbolic level of membership" (Dumbrava 2016, 1500). After the fall of the Soviet bloc, many Eastern European countries experienced a dramatic reduction of fertility rates and an increase in emigration flows. At the same time as policymakers in Romania argued for the need to meet the "historical duty" to co-ethnics and for a recreation of the pre-communist nation (Dumbrava 2016, 1500), Romani people living in Romania faced criticism concerning their "excessive reproduction" (Dumbrava 2016, 1497). These micro and macro biopolitics not only reproduce racist discourses but also tend to favor "children 'as white as possible" (Dumbrava 2016, 1497).

The offering of citizenship to co-ethnics from Moldova and Ukraine can be seen as a way to bring culturally compatible workers and white reproductive agents into the country. However, these "suitable citizens" that are flexible enough to respond to demographic challenges and market needs in Romania had their own goals and the strategy mostly failed as the majority 
directly moved to "Western" European countries in search of better-paid labor (Dumbrava 2016, 1501).

\section{Bilateral agreements}

Agricultural workers from Moldova without European citizenship and outside the Stagiaires Agreements only have access to the European labor market if they work in Poland. Since 2006, certain non-Europeans can be employed without the need to obtain a work permit. The employer's declaration system allows workers from Russia, Ukraine and Belarus to stay for three months within a six-month period in Poland. At first, this possibility was limited to the agricultural sector, where labor was most needed, but it opened to all sectors over the following years. In 2009, Moldova and Georgia were brought into this declaration system, as a legal basis was given via the EU Mobility Partnership with third countries. Until now, no quantitative data is available about this partnership. My observations show that most people from Moldova are working in the agrifood sector, mainly in the meatprocessing industry. One of the reasons for this is that people living in Poland refuse to work for such low salaries, as EU membership has opened the labor market of higher-income countries to them. While many agricultural workers in Switzerland, Norway, Belgium, Germany, the Netherlands and England come from Poland, the Polish agricultural sector is facing a "gap". Temporary workers on Polish farms and in the meat-processing industry increasingly also come from Ukraine, especially after the outbreak of war in 2014 (Jaroszewicz 2018, 6). In 2013217.571 Ukrainian citizens were registered in the declaration system in Poland - a number that rose to 1.7 million in 2017 (Jaroszewicz 2018, 7), most of them working in the agricultural sector (Jaroszewicz 2018, 13). Poland has one of the highest inflows of "seasonal" / short-term labor migration on a worldwide scale (Jaroszewicz 2018, 6). A new act for a temporary stay permits due to seasonal work is in effect since 2018, allowing temporary work permits for a duration of up to nine months within 
one year. Permits can now be issued to workers from any country but only in agriculture, the agrifood sector, horticulture and tourism.

Staff from recruitment agencies in Moldova told me that the Polish meat-processing industry is the most in need of workers and therefore the most important recruitment partner. The managers in those factories are often also from Moldova, so agencies can broker workers without language skills into the Polish food processing industry. The brokers face serious difficulties mediating people, as salaries are very low and working conditions disastrous. People work six days a week, often for more than 14 hours a day because civil law in Poland allows 24-hour workdays. The labor conditions in the processing industry are the most exploitative and those in Poland have the lowest wages. The poorest of the poor work here - those with little social, cultural and economic capital who cannot manage to get citizenship in Europe or cannot claim Romanian or Bulgarian co-ethnicity. Many people do not want or cannot carry out their contracts because of deteriorating health; they often work without health insurance. Others uphold their work positions until they have Romanian citizenship and are allowed to move on to work in wealthier European countries. Sometimes these workers continue toiling in the meat-processing industry. The same agencies in Moldova that recruited them to work in Poland later broker them to slaughterhouses in Germany. The agencies I talked to collaborate with the biggest food processing companies in Poland and Germany and, to mitigate labor shortages in summers, they have "special offers" where workers are exempted from fees.

\section{Circular migration policies}

Signs in cities and the countryside in Moldova advertise "Lucru Legal în Polonia" (legal work in Poland), trying to demonstrate credibility for better recruitment. The need to point to the legal status of employment are probably based on traumatizing experiences mainly of rural communities due to coercive labor relations and international trafficking (Meshelemiah and Lynch $2019,353)$. In certain cases, especially people from villages had been recruited 
for work but were then made to sell their organs (Lundin 2012, 229). This community knowledge created mistrust that agencies probably try to counter by referring to the legality of the offered labor relations. A law implemented in 2008 (no. 180-XVI, 10.07.2008) includes the regulation that agencies need to apply for a license before recruiting Moldovan citizens for work abroad. This implies several stipulations for recruitment agencies. NEXUS, which operates in six different cities throughout the country, is the most visible officially registered agency in Moldova. As an NGO they also provide social services while mediating people for working abroad. The staff criticizes informal, nonregistered and unauthorized agencies from outside the country that do not adhere to the official rules:

"We have a large informal sector in the country. And a bad legislation towards that. It is over-regulated. We have unbelievably many laws to be considered concerning employment like private job service. At the same time, there is no punishment for those working in the informal sector. Hence informal agencies run just like regular companies. That is why we have many agencies effectively working informally. (...) I know job agencies from the Netherlands, which operate officially [in their home countries]. They have the necessary certificates, they are officially registered, they have been running for a long time. Then, they come to Chisinau, open offices, do not register and recruit people. The same with companies from Denmark." (Interview with NEXUS staff in Chișinău 2017)

NEXUS staff refers to their recruitment engagement as good practice: their mediation services for people from Moldova who seek work abroad include the provision of language courses and legal training - a service they deny agencies from the Netherlands and Denmark. My investigations (informal talks, internet inquiry, visits of agencies) confirm that recruitment for Denmark - which is mainly organized on Facebook, followed by interviews every couple of months - takes place without considering local provisions.

NGOs such as NEXUS and IOs are also part of the recruitment infrastructure. But what are their goals and structural roles? NEXUS has 
operated in Moldova since 2012 when the Austrian NGO International Agency for Source Country Information (IASCI) - whose founder and director previously worked for the International Organization of Migration (IOM) - received funds from the European Union. The Swiss Agency for Development and Cooperation (SDC) contributed 650,000 Swiss Francs in the first period (2012-2015) and completely financed the second period (20152018). The NGO's recruitment framework is built within the circular migration model.

"The project was about strengthening the link between migration and development by testing an integrated service provider to Moldovan migrants and their communities. The prototype of this service provider was called NEXUS. The idea behind NEXUS was to support migrants to migrate smarter and return better by offering practical guidance in all stages of migration, such as pre-departure, period in migration, and return. (...) Supporting circular migration is at the core of this initiative. (...) The NEXUS project is part of a larger Migration and Development program financed by SDC in Moldova with the aim of promoting innovative interventions harnessing the development potential of migrants." (Staff of the Federal Department of Foreign Affairs (FDA), head of the Swiss Agency for Development and Cooperation 2018)

Under the motto, "migrate smarter, return better" the aim is to prepare people to work abroad, mediate the process and motivate them to invest their savings into Moldova's economy. This is understood as an innovative development strategy. Staying in contact with the people working abroad is therefore one of the tasks of NEXUS to make sure that the savings are coming back to Moldova. An office in Paris, one of the destination countries, has been opened to offer free language courses, legal help and to organize social events with the aim of establishing a Moldovan diaspora community abroad. This overall strategy is reflected in the Moldavan government's "Diaspora-2025 national strategy", issued in 2016.

NEXUS' promotion of circular migration in Moldova is embedded in the European migration management policy: "The Commission believes that 
the links between migration and development offer a significant potential for furthering development goals" (referring to Millennium Development Goals) (EC 2005, 2). Circular migration is said to be a development strategy firstly by "fostering cheap, fast and secure ways to send remittances" (ibid. 4) along creating a diaspora abroad (ibid. 6), secondly by minimizing care/brain drain (ibid. 8) and thirdly by "disciplining recruitment" (ibid. 9). The latter includes "facilitating return migration" (ibid. 12) along "tackle roots" and finding tools to reduce so-called illegal migration (ibid. 12). Since 2005, the EU has put several million Euros into projects and has implemented mobility partnerships (EC 2007, i.a.) on the basis of which bilateral agreements between European Union member states and third countries can be signed to facilitate rights-based "circular" labor migration. In 2008 the Republic of Moldova along the Republic of Cape Verde became the first partners (see for Moldova, Council of the European Union 2008). It is based on this mobility partnership that the aforementioned working relations between Moldova and Poland were installed. In this broader context, the introduction of NEXUS is one of many steps towards the institutionalization of "circular migration" policies. This concept of "circular migration" has been framed as a "triple win" situation for "the host society whose labor shortages will be filled; the migrant who will have greater opportunities to increase his/her employability; and the country of origin which will benefit from remittances as well as newlyacquired skills of returning migrants" (European Migration Network 2010). According to this narrative, everybody wins: the "receiving" and "sending" countries as well as the migrating workers.

However, authorities are facing certain challenges, as people and their movements cannot be perfectly managed and controlled. NEXUS is facing the fact that people prefer to stay abroad as soon as they are able, refusing to go back and forth. Hence, the SDC reorganized their vision in its Cooperation Strategy for 2018-2021:

“The Swiss Agency for Development and Cooperation will place a stronger emphasis on the push factors for migration, enabling the creation of conditions that motivate migrants to return or invest in their home country 
D. Bolokan - Recruitment infrastructure within the agricultural and agrifood sector ...

and discourage potential migrants from leaving». (Interview with FDFA staff 2018)

Making sure that the workers go back to their home countries after their work ends will be the focus, following the overall strategy and central part of the "circular migration" policy and a stipulation that the "sending countries" must commit to. At the same time, the follow-up project is supposed to focus more strongly on the regulation of immigration as well.

These development and mobility strategies that facilitate "circular migration" have to be connected to further agreements such as the one between Moldova and Switzerland on the readmission of persons residing without authorization (Rückübernahmeabkommen von Personen mit unbefugtem Aufenthalt). It has been updated in May 2010 and builds the basis for deportation if a person has overstayed their authorized period of admission. Due to such regulations, the International Organization for Migration (IOM) in Moldova installed an Assisted Voluntary Return Program for Moldovan citizens living in illegalized situations abroad in 2006.

"People can contact us if they don't want to be deported and wish to come back on a voluntary basis. We buy airplane tickets for them and we make the documents if the person doesn't have them anymore. Through our diplomatic relations we are hence able to bring back the citizen without being deported, without paying fees and without being put on a country's black list." (Interview with IOM staff in Chișinău 2017)

While the IOM tries to bypass the criminalization of workers, these diplomatic arrangements that allow illegalized individuals for a less repressive return coincide with the aim of 'circulation' and further serve "migration flows" (and "remittances flows" see EC 2005).

\section{Recruitment infrastructure within post-Soviet and neocolonial agricultural labor regimes in Europe}

The aim of this article is to develop a genealogical perspective on recruitment infrastructure while looking into the current hypermobility of workers and 
regimes of labor rotation within the agricultural and agrifood sector. This was done to change the starting point of reflection on current labor conditions and the division of labor in the context of food production in Europe. Although there is more public discussion during the COVID-19 pandemic about agricultural working and living conditions than before, the horizon of the reflections ultimately remains exactly where most analysis in the social sciences is located: within questions of system preservation. Whereas some scholars indeed criticized labor conditions by pointing to the continuities of current temporary labor recruitment with guestworker schemes after the Second World War, Ha has argued that this view risks a "secondary colonialization" as it is based on a political "hour-zero-myth"; in this sense, labor migration policies are de-historicized and de-problematized and colonial patterns that trace back to the Imperial era in Europe are invisibilized (Ha 2003, 2008, 2016). This crucial argument has to be taken into consideration while looking into current migration policies in general and labor recruitment within the agricultural sector more specifically. This raises the following question: how exactly do modernized regimes of labor control within the recruitment infrastructure between Moldova and the EU/Switzerland reveal instaurations of colonial patterns?

The implementation of a recruitment infrastructure in Switzerland, as in Germany and other European countries, clearly shows what is still valid today: state policies of labor migration have institutionalized a set of legal tools to regulate and control "human resources". Workers are recruited when needed and then sent back to save the cost of the (re)production of the workers. The legacy of the "waiting period regulation" (Karenzzeit-Regelung) from Imperial Germany, the Seasonal Enrolment Statute (Saisonnierstatut) in Switzerland from the period after the First World War, and the Guest-worker program after the Second World war in Germany are today reflected in Circular Migration policies. These implementations, along with further regulatory political tools, share the very same goal of recruiting workers justin-time for different regional and transnational rotation regimes while excluding them from the rights that local workers have. This very colonial 
pattern - implementing rotation regimes of workers according to market needs while devaluing people on different levels, regulating their lives and appropriating the care and (re)productive capacities of their communities in the global peripheries - builds the basis of what Ha describes as the reversal of colonial forms of expansion.

Colonial patterns are further represented in different attempts to regain access to "Eastern" Europe as a recruitment zone. Historians have shown how these regions have been treated as the "hunting ground" and "human resource warehouse" of Imperial Germany (see Ha 2003, 78), which was been lost after the Second World War and remained inaccessible during the Cold War. The collapse of the Soviet Union and the later enlargement of the European Union with "the East", including the institutionalization of bilateral labor agreements, reveal ideological instaurations of internal colonization. As Ha points out that this is represented in the fundamental element of possessing the power, goal and ability to organize and control human resources. I argue that today's labor arrangements and recruitment in the agricultural sector in Europe have to be situated within these entanglements. These entanglements reveal the interdependence of post-Soviet and neocolonial labor regimes regimes of labor control - that follow a colonial ideology and reveal neocolonial structures of exploitation. Within this context, Poland has a new role, as it is increasingly becoming one of the most important "sending" and "receiving" countries within the agricultural and agrifood labor market: the recruitment of workers from Poland to practically all wealthier European countries comes along agricultural recruitment chains that involve workers from Ukraine and Moldova. The implementation of such bilateral agreements also shows that it is the agricultural sector that is at the forefront when labor recruitment programs and policies are being implemented. Labor recruitment and the agricultural sector are hence strongly connected to the legal expansion of the overall recruitment infrastructure of workers. Patterns of guestworker regimes that have come into being in the context of Imperial Europe are today not only to be found at the national state level but in the overall direction of 
European policy. This is most clearly reflected in the mobility regime of circular migration.

Neocolonial labor regimes that entangle with post-Soviet policies further reveal the following crucial colonial pattern: hierarchization through ethnicization/racialization of people. This is most visible in the introduction of citizenship practices with biopolitical implications: maintaining a "European" national body comes with different forms of hierarchization of workers. It excludes those that can and those that cannot claim "European" ancestry. This again reveals a colonial pattern and a continuity of naturalizing discrimination and labor exploitation. Ha has pointed to the German racism towards workers from Poland during Imperial Germany that labeled them as "born earth workers". According to this example, Ha states that "racism does not require a visible colour line" (Ha 2008, 83). The citizenship practices recreate ethnicized hierarchical structures and re-institutionalize an "Eastern European" ethclass that is strongly connected to those sectors: they are, along with other migrating workers from postcolonial regions, the least paid and most exploited. While the forced flexibilization and rotation of agricultural workers through various legal interventions forces people into hypermobile lives, this constant movement is also connected to the recruitment of a workforce that is constructed as co-ethnic to certain European nations, as "white" and considered "culturally compatible" through ancestral belonging.

At the same time Romani communities are discriminated as notbelonging. In a broader historical and European-wide context their stateenforced mobility is invisibilized and people are constructed as not "sedentary" (Y1ld1z \& Genova 2018). Not being "sedentary" can be used as a way to devaluate communities (Thornton 2014,115) and simultaneously as a source of appropriation and as a way to naturalize exploitative labor relations: referring to the circularity of migration within the circular migration framework implies that this transnational labor pattern is "organic" and therefore "natural" (read: people have always moved). This discourse that considers recruitment and rotation systems to be natural also carries the notion of "sustainable" migration (read: good and helpful in the long-term). I 
argue that this framework comes with a set of naturalizing implicit logics that discursively colonizes social practices, linking them to nomadic movements based on seasonality. These colonizing practices are authorized and strengthened by academic interventions; in the tradition of colonial scientists, exploitative systems like circular migration schemes are just "part of the changing nature of migration" (Solé et al. 2016) and Eastern Europe as regarded as a limited, but possible "source of skilled agricultural labour" (Kvartiuk 2015).

In addition to naturalizing policies of exploitation such as those of circular migration, this framework has been introduced as a "triple-win" solution that promotes hypermobile living and working relations under the guise of development, thereby revealing the colonial narrative of aid. The win-win-win master plan argues that all involved sides win, as "receiving countries" can fill their labor shortage in sectors that need workers, "sending countries" can receive remittances, and the involved workers and their communities benefit from a lessening of the brain/care drain. What the political economy of circular migration aims for and results in is the following: (1) "receiving" countries maintain precarious sectors where locals refuse to work. They build a recruitment infrastructure that allows for upward mobility for the local precarious working class through the ethnicization of specific sectors (see Inländerprimat/ domestic primacy). This primacy provides for a general preference for Swiss/EU citizens and is hence, revealing an ethclass/underclass while at the same time serving capital accumulation and welfare reduction. (2) The ruling classes in the "sending" countries such as in Moldova do not need to look for local ways to reduce precarity to keep the social peace; they instead send people away with "reintegration" programs so that people come back, bringing their money and taking care of their grandchildren while their children, under the regulation of the authorities, continue toiling in a "circular" manner abroad. One could certainly say that the re-articulation of labor recruitment as aid reveals continuity with German guestworker schemes that were framed to be development aid and as a contribution to European integration (Herbert and Hunn 2007, 704-705). The 
modernized argument for the implementation of circular migration is hinting at the promise of more "development" for the "underdeveloped" while countering care/brain drain. But what it actually reveals is a colonial pattern that Madina Tlostanova describes as a rhetoric of salvation, such as "the civilizing missions". This rhetoric of salvation that appears under different faces is in fact "hiding the colonial logic of control, domination and suppression, a missionary syndrome paradigmatic of the modern/colonial matrix of power." (Tlostanova 2012, 132).

It was somehow surprising to find that the most visible brokering structure in Moldova promoting the "circular" migration concept is financed by Swiss development money and thereby institutionalized with the help of Swiss authorities. At the same time, it reveals the leading role that Switzerland plays in the implementation of "development aid" projects that above all recruit workers for richer European countries. This continuity of a pioneering role in developing recruitment strategies, even before Imperial Germany, (along with the pioneering role in developing racial hygiene laws that later inspired Nazi Germany, see Wecker 2012), should strongly be pointed out here. It also makes visible - as Ha argues in the context of Imperial Germany - that it would be surprising if colonial ideologies did not somehow impact labor and migration policies. In the same way, the European Union's ideologies that allowed for the death of thousands of people in the Mediterranean - as "Fortress Europe" closed its borders - are not disconnected from European policies that are increasingly installing "revolving doors" for workers, especially at its eastern borders. So, while a white, European ethclass is constructed and institutionalized, their mobility is controlled by different stakeholders that, under the umbrella of humanitarian aid, facilitate regulation and mediation: There is the IOM that "brings back" illegalized Moldovan citizens via diplomatic arrangements that "free" them from being sanctioned because they overstay their work permit. There is also the Swiss Agency for Development and Cooperation that helped install a circular migration program (see NEXUS) and finances the trainee programs (see Stagiaires agreements). These organizations do not simply 
allow for "smooth" recruitment flows, but could be seen as pioneering modernized regimes of recruitment and labor control that reveal colonial patterns in post-Soviet and postcolonial times.

\section{Conclusion and the need for an abolitionist perspective on recruitment}

The strategy of asking for more regulation to achieve social justice is a widespread consensus among researchers in migration studies. I argue that this common practice of pointing to underregulated labor conditions (see Nita 2016) such as further practices of asking for more control, derives from the very same ideology that it ostensibly tries to cure. It does so by using the same oppressive tools - management and control - to attempt repair. In order to escape this developmentalist position, I depart from an epistemological and political position influenced by the reflections of Audre Lorde, who says that "the master's tools will never dismantle the master's house." Multilateral agreements on circular migration have to be considered as further examples of the "master's tools".

The genealogical perspective on worker's recruitment infrastructure allowed a different point of departure. It enabled the relations between Switzerland/ the EU and Moldova to be historically situated next to those of Germany and Eastern Europe during the colonial era while drawing on the instauration of power within highly regulated labor (hyper)mobility and circular migration policies. Analyzing how the contemporary migration management, post-Soviet citizenship policies and labor recruitment is embedded within a broader power matrix of a racialized, colonized and exploitative appropriation of the "East" European labor force shows how on a macro level the "East" European peripheries, such as rural Moldova, are (still and again) treated as a dependent region. I conclude that not just neoliberalism but neocolonialism is at the root of regimes of rotation - an ideology that derives from the very colonial practice and slaveholder mindset that people can be recruited and sent back-and-forth as if they were goods. These movements are regulated according to market needs and the needs and 
desires of the migrating workers themselves are not seriously considered at a structural level.

This article is limited in the way that it is not able to grasp the whole picture of agricultural labor recruitment within Europe nor resistance in this context. Due to the focus of my research, I was only able to look at the entanglements between Moldova and Switzerland/ the EU. An analysis of resistance practices as well as further entanglements and regions such as postcolonial Africa and Latin America, where many agricultural workers also come to Europe from, is lacking. This mapping draws attention to the genealogies of hypermobility, circularity and rotation, advancing our understanding of the under-researched but deeply neocolonial foundation of labor recruitment and policies of "circular" migration in Europe. Further endeavors could advance these research perspectives, taking into consideration the postcolonial and the post-Soviet as they are entangled in current European labor regimes. A subsequent intersectional research perspective on labor relations and on resistance is urgently needed and would include differentiated personal experiences of class, age, gender, sexual identities and religion. I propose this as a basis to question the master's tools in order to decolonize research and the limited understandings and consumer-based critiques, including the widespread delegation ethos on food production in which (re)production is outsourced and political responsibility is passed to authorities. This would enable and empower us to ask questions concerning the decolonization of agricultural labor relations and further change the point of departure in order for us to (re)search toward the appropriate abolitionist steps.

\section{References}

Azzeruoli, Vanessa. 2017. "The (sacred) cow business: narratives and practices of the "ethnic niche" of Indian Punjab milkers in the Po Valley." In Migration and Agriculture: Mobility and Change in the Mediterranean Area, edited by Alessandra Corrado, Carlos de Castro, 
D. Bolokan - Recruitment infrastructure within the agricultural and agrifood sector ...

Domenico Perrotta, 27-41. London and New York: Routledge/Taylor \& Francis Group.

Bade, Klaus Jürgen. 1984. Auswanderer - Wanderarbeiter - Gastarbeiter: Bevölkerung, Arbeitsmarkt und Wanderung in Deutschland seit der Mitte des 19. Jahrhunderts. Ostfildern: Scripta Mercaturae.

Bade, Klaus Jürgen. 1992. Deutsche im Ausland - Fremd in Deutschland; Migration in Geschichte und Gegenwart. München: Beck.

Bade, Klaus Jürgen. [1979] 2005. "Transnationale Migration und Arbeitsmarkt. Land oder Arbeit? Transnationale und interne Migration im deutschen Nordosten vor dem Ersten Weltkrieg." Habilitation thesis.

Bade, Klaus Jürgen. 2001. Europa in Bewegung. Migration vom späten 18. Jahrhundert bis zur Gegenwart. München: Beck.

Bauder, Harald. 2014. "Why We Should Use the Term 'Illegalized' Refugee or Immigrant: A Commentary." International Journal of Refugee Law 26, no. 3: 327-332. https://doi.org/10.1093/ijrl/eeu032.

Bolokan, Dina. (in press). "On hypermobility in the agricultural sector in Europe - translocal life trajectories between Switzerland and Moldova." In The Rural-Migration Nexus: global problems, rural issues, edited by Kerrigan, Nathan, and de Lima, Philomena. London: Palgrave.

Castles, Stephen. 2006. "Guestworker in Europe: A Resurrection?" International Migration Review 40 (1): 741-66. https://doi.org/10.1111/j.1747-7379.2006.00042.x.

Chantal, Crenn. 2017. "Wine heritage and the ethnicization of labour: Arab workers in the Bordeaux vineyards." In Migration and Agriculture: Mobility and Change in the Mediterranean Area, edited by Alessandra Corrado, Carlos de Castro, Domenico Perrotta, 42-57. Routledge/Taylor \& Francis Group.

Consterdine, Erica and Sahizer Samuk. 2015. "Closing the Seasonal Agricultural Workers' Scheme: A Triple Loss." Working Paper No. 83. University of Sussex: Sussex Centre for Migration Research. https://bit.ly/21Rzgmw.

Corrado, Alessandra, Carlos de Castro and Domenico Perrotta. 2017. Migration and Agriculture: Mobility and change in the Mediterranean area. London and New York: Routledge.

Council of the European Union. 2008. "Joint Declaration on a Mobility Partnerships between the European Union and the Republic of Moldova." Accessed December 29, 2020. https://ec.europa.eu/homeaffairs/sites/homeaffairs/files/what-we-do/policies/international- 
D. Bolokan - Recruitment infrastructure within the agricultural and agrifood sector ...

affairs/global-approach-to-migration/specific-

tools/docs/mobility_partnership_republic_of_moldova_en.pdf.

Dumbrava, Costica. 2016. "Reproducing the nation: reproduction, citizenship and ethno-demographic survival in post-communist Romania." Journal of Ethnic and Migration Studies 43 (1): 1490-1507. https://doi.org/10.1080/1369183X.2016.1221335.

Dumbrava, Costica. 2019. "The ethno-demographic impact of coethniccitizenship in Central and Eastern Europe." Journal of Ethnic and Migration Studies 45 (6): 958-974. https://doi.org/10.1080/1369183X.2018.1440490.

European Commission. 2005. "Migration and Development: Some concrete orientations." Accessed December 29, 2020. https://eur-lex.europa. eu/LexUriServ/LexUriServ.do?uri=COM:2005:0390:FIN:EN:PDF.

European Commission. 2007. "On circular migration and mobility partnerships between the European Union and third countries." Accessed December 29, 2020. https://ec.europa.eu/commission/ presscorner/detail/en/MEMO_07_197.

European Commission. 2020. "Guidelines on Seasonal Workers in the EU in the Context of the Covid-19 Outbreak." Brussels, 17 July 2020. Accessed December 29, 2020.

https:/ / ec.europa.eu/social/BlobServlet?docId=22866\&langId=en.

European Migration Network. 2011. "Synthesis Report - Temporary and Circular Migration." Accessed December 29, 2020. https://ec.europa.eu/home-affairs/sites/homeaffairs/files/whatwe-do/networks/european_migration_network/reports/docs/emnstudies/circular-migration/0a_emn_synthesis_report_ temporary_circular_migration_final_sept_2011_en.pdf.

Food and Agricultural Organization of the United Nations (FAO). 2020. Migrant workers and the COVID-19 pandemic. http://www.fao.org/3/ca8559en/CA8559EN.pdf.

Foucault, Michel. 1977. "Nietzsche, Genealogy, History." In Language, Counter-Memory, Practice: Selected Essays and Interviews, edited by Donald F. Bouchard, 139-164. Ithaca: Cornell University Press.

Frigerio, Marina. 2014. Verbotene Kinder. Die Kinder der italienischen Saisonniers erzählen von Trennung und Illegalität. Zürich: Rotpunktverlag.

Gertel, Jörg and Sarah Ruth Sippel. 2014. Seasonal Workers in Mediterranean Agriculture. London: Routledge.

Ha, Kien Nghi. 2003. "Spricht die Subalterne deutsch? Migration und postkoloniale Kritik." In Die Kolonialen Muster Deutscher 
D. Bolokan - Recruitment infrastructure within the agricultural and agrifood sector ...

Arbeitsmigrationspolitik, edited by Encarnación Gutiérrez Rodríguez, Hito Steyerl, 56-107. Münster: Unrast.

Ha, Kien Nghi. 2008. "Erdarbeiter"- "Gastarbeiter"- "Computer-Inder": Arbeitsmigrationspolitik und innere Kolonisierung. In Deplatziert! Interventionen postkolonialer Kritik, edited by Stephan Cohrs and Nadine Golly, 16-36. Berlin: Wissenschaftlicher Verlag Berlin.

Ha, Kien Nghi. 2016. "Billig und willig". Arbeitsmigrations- und Integrationspolitik aus postkolonialer Perspektive. In Postkoloniale Politikwissenschaft, edited by Aram Ziai, 173-190. Bielefeld: transcript Verlag.

Hellio, Emmanuelle. 2008. "Importer des femmes pour exporter des fraises (Huelva)". Études rurales 182: 185-200. https://doi.org/10.4000/etudesrurales.8867.

Herbert, Ulrich and Karin Hunn. 2007. "Beschäftigung, Soziale Sicherung und soziale Integration von Ausländern." In Geschichte der Sozialpolitik in Deutschland seit 1945, edited by Michael Ruck and Marcel Boldorf, 685724. Baden-Baden: Nomos.

Jamin, Mathilde. 1998. “Die deutsch-türkische Anwerbevereinbarung von 1961 und 1964." In Fremde Heimat. Eine Geschichte der Einwanderung aus der Türkei, edited by Aytaç Eryllmaz and Mathilde Jamin, 69-82. Essen: Klartext-Verlag.

Jaroszewicz, Marta, 2018. "Migration from Ukraine to Poland. The trend stabilises." Warsaw: Ośrodek Studiów Wschodnich. https://www.osw.waw.pl/sites/default/files/Report_Migration $\% 2$ Ofrom\%20Ukraine_net.pdf.

Knott, Eleanor. 2019. "Strategy, identity or legitimacy? Analysing engagement with dual citizenship from the bottom-up." Journal of Ethnic and Migration Studies 45 (6): 994-1014. https://doi.org/10.1080/1369183X.2018.1440494.

Kvartiuk, Vasyl. 2015. “Osteuropa als Quelle für landwirtschaftliche Fachkräfte in Deutschland?" Berichte über Landwirtschaft 93 (3): 1-22. https://doi.org/10.12767/buel.v93i3.78.

Lorde, Audre. [1979] 1984. "The Master's Tools Will Never Dismantle the Master's House." In Sister Outsider: Essays and Speeches, edited by Audre Lord, 110-113. California: Crossing Press.

Lundin, Susanne. 2012. “Organ economy: organ trafficking in Moldova and Israel". Public Understanding of Science 21 (2): 226-241. https://doi.org/10.1177/0963662510372735.

Martin, Philip Martin. 2017. Merchants of Labor: Recruiters and International Labor Migration. Oxford University Press. 
Meshelemiah, Jacquelyn C.A. and Raven E. Lynch. 2019. The cause and consequence of human trafficking: Human rights violations. Ohio: The Ohio State University Pressbook.

Molinero-Gerbeau, Yoan, and Gennaro Avallone. 2016. "Producing Cheap Food and Labour: Migrations and Agriculture in the Capitalistic World-Ecology." Social Change Review 14 (2): 121-148. https://doi.org/10.1515/scr-2016-0025.

Morice, Alain and Bénédicte Michalon. 2008. “Les migrants dans l'agriculture: vers une crise de main-d'oeuvre?" Études rurales 182: 9-28. https://doi.org/10.4000/etudesrurales.8749.

National Bureau of Statistics of the Republic of Moldova. 2020. Accessed December 29, 2020. http:/ / statbank.statistica.md.

Necșuțu, Madalin. (2020). BalkanInsights. Accessed December 29, 2020. https:// balkaninsight.com/2020/05/25/moldova-pm-sparks-feudwith-romania-over-corruption-claim/.

Nita, Sonja. 2016. "Circular Migration Within the EU-Moldova Mobility Partnership." In Impact of Circular Migration on Human, Political and Civil Rights: A Global Perspective, edited by Carlota Solé, Sonia Parella, Teresa Sordé Martí and Sonja Nita, 23-44. United Nations University Series on Regionalism. Springer International Publishing, Cham.

Pagenstecher, Cord. 1994. Ausländerpolitik und Immigrantenidentität. Zur Geschichte der "Gastarbeiter" in der Bundesrepublik. Berlin: Dieter Bertz Verlag.

Peano, Irene. 2017. "Global care-commodity chains: Labour re/production and agribusiness in the district of Foggia, southeastern Italy." Sociologia del lavoro. https:/ / doi.org/10.3280/SL2017-146002.

Perrotta, Domenico. 2015. "Agricultural Day Laborers in Southern Italy: Forms of Mobility and Resistance." South Atlantic Quarterly 114 (1): 195-203. https://doi.org/10.1215/00382876-2831632.

Perrotta, Domenico Claudio and Devi Sacchetto. 2014. "Migrant farmworkers in Southern Italy: ghettoes, caporalato and collective action." Workers of the World 1 (5): 75-99.

SEM. 2019. "Wegleitung für Junge Berufsleute. Zulassung zur Erwerbstätigkeit in der Schweiz im Rahmen der internationalen Stagiaires-Abkommen (nach Art. 30 AIG und Art. 42 VZAE)." Accessed: December 29, 2020. https://www.sem.admin.ch/dam /sem/de/data/arbeit/berufspraktikum/ausl-stagiaires-CHEd.pdf.download.pdf/ausl-stagiaires-CHE-d.pdf.

SEM. 2020. "Weisung und Erläuterungen Ausländerbereich (Weisungen AIG). Kapitel 4." Accessed: December 29, 2020. 
D. Bolokan - Recruitment infrastructure within the agricultural and agrifood sector ...

www.sem.admin.ch/dam/sem/de/data/rechtsgrundlagen/weisun gen/auslaender/weisungen-aug-kap4-d.pdf.

Solé, Carlota, Sonia Parella, Teresa Sordé Martí and Sonja Nita. 2016. Impact of Circular Migration on Human, Political and Civil Rights: A Global Perspective. United Nations University Series on Regionalism. Springer International Publishing, Cham.

Szulecka, Monika. 2016. "Regulating Movement of the Very Mobile: Selected Legal and Policy Aspects of Ukrainian Migration to EU Countries." In Ukrainian Migration to the European Union. Lessons from Migration Studies, edited by Olena Fedyuk and Marta Kindler, 51-71. Switzerland: Springer International Publishing AG.

Swiss Farmers' Union. 2005. "Jahresbericht 2005." Accessed December 29, 2020.https://www.sbv-usp.ch/fileadmin/sbvuspch/03_Ueber_uns/ Jahresberichte/Jahresbericht_05_d.pdf.

Tlostanova, Madina. 2012. "Postsocialist $\neq$ postcolonial? On post-Soviet imaginary and global coloniality." Journal of Postcolonial Writing 48: 130-142. https://doi.org/10.1080/17449855.2012.658244.

Thornton, Gabriela Marin. 2014. "The Outsiders: Power Differentials between Roma and Non-Roma in Europe." Perspectives on European Politics and Society 15, no. 1: 106-119. https://doi.org/10.1080/15705854.2013.873260.

Ulrich, Herbert. 2003. "Geschichte der Ausländerpolitik." Deutschland. Bundeszentrale für politische Bildung.

Wecker, Regina. 2012. "Eugenics in Switzerland before and after 1945 - a Continuum?" Journal of Modern European History 10 (4): 519-539.

Yıldız, Can and Nicholas De Genova. 2018. "Un/Free mobility: Roma migrants in the European Union." Social Identities 24 (4): 425-441. https://doi.org/10.1080/13504630.2017.1335819.

Xiang, Biao and Johan Lindquist. 2014. "Migration Infrastructure." International Migration Review 48: 122-148.

https://doi.org/10.1111/imre.12141. 